\title{
Hepatic amyloidosis: a cause of rapidly progressive jaundice
}

\author{
Mark Ford, ${ }_{1}^{1}$ Benjamin Disney, ${ }^{2}$ Veena Shinde, ${ }^{3}$ Sauid Ishaq ${ }^{4}$
}

'Department of Rheumatology, Queen Elizabeth Hospital Birmingham, Birmingham, UK ${ }^{2}$ Department of

Gastroenterology, University Hospitals Coventry and Warwickshire NHS Trust, Coventry, UK

${ }^{3}$ Department of Histopathology, Dudley Group of Hospital, Dudley, UK

${ }^{4}$ Department of

Gastroenterology, Dudley Group of Hospital, Dudley, UK

\section{Correspondence to Dr Benjamin Disney, b.disney@nhs.net}

Accepted 9 December 2017

To cite: Ford M, Disney B, Shinde V, et al. BMJ Case Rep Published Online First: [please include Day Month Year]. doi:10.1136/bcr-2017 222942

\section{DESCRIPTION}

An 83-year-old man presented with an acute history of weight loss and jaundice. He had a history of type 2 diabetes mellitus and hypertension. He consumed 30 units of alcohol per week.

The patient was cachectic and jaundiced with non-tender hepatomegaly and no evidence of chronic liver disease. There was evidence of hypoalbuminaemia (albumin $25 \mathrm{~g} / \mathrm{L}$, reference 34-51 g/L), hyperbilirubinaemia (bilirubin $188 \mu \mathrm{mol} / \mathrm{L}$, reference $<22 \mu \mathrm{mol} / \mathrm{L})$ and a raised alkaline phosphatase (629 IU/L, reference 35-105 IU/L). Full blood count, coagulation tests and the remaining liver function tests were normal. An estimated Glomerular filtration rate (eGFR) was $71 \mathrm{~mL} /$ $\min / 1.73 \mathrm{~m}^{2}$. Autoantibodies and immunoglobulins were normal. Hepatitis viral serology was negative. Serum light chain measurements revealed kappa chain concentration of 13.3 (reference $3.3-19.4 \mathrm{mg} / \mathrm{L}$ ) and lambda chain concentration of 28.5 (reference $5.7-26.6 \mathrm{mg} / \mathrm{L}$ ) with a ratio of 0.47 (reference 0.26-1.75). A CT abdomen revealed hepatomegaly and ascites. He subsequently had a liver biopsy (figures 1-3). The histology from the liver biopsy demonstrates hepatic amyloid with extensive deposition of extracellular hyaline material (figure 1A,B). Staining with Congo red shows characteristic salmon pink amorphous material (figure 2). Lambda staining shows diffuse positivity confirming AL-type amyloidosis (figure 3). A bone marrow biopsy revealed no evidence of bone marrow plasmacytosis or amyloid deposition.

Three weeks later, liver function deteriorated (bilirubin $349 \mu \mathrm{mol} / \mathrm{L}$, alkaline phosphatase $1072 \mathrm{IU} / \mathrm{L}$ ). Additionally, there was progressive kidney injury (eGFR $39 \mathrm{~mL} / \mathrm{min} / 1.73 \mathrm{~m}^{2}$ ) with evidence of microalbuminuria (albumin:creatinine ratio $3.1 \mathrm{mg} / \mathrm{mmol}$ ) presumed secondary to renal amyloid involvement.

Amyloidosis involves a complex pathway of extracellular protein deposition and poses significant diagnostic and treatment challenges. The most common subtype is primary/amyloid-light chain (AL) amyloidosis due to haematological disorders, commonly clonal plasma cell disorders. Secondary/ Amyloid A (AA) amyloidosis due to chronic

A
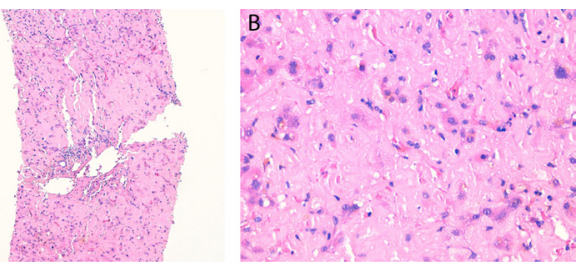

Figure $1 \quad(A, B)$ Hepatic amyloid deposition.

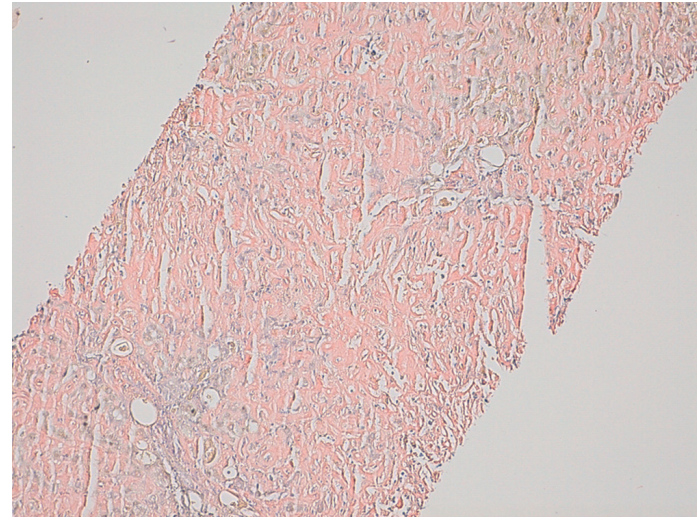

Figure 2 Hepatic amyloid deposition (Congo red stain).

inflammation, infection or malignancy has become less common in recent years due to advancement in treatment for these conditions. Transthyretin (ATTR) amyloidosis is now the second most common subtype in the UK and includes wild-type ATTR (previously known as systemic senile amyloidosis) and hereditary ATTR. ${ }^{1}$

The deposition of protein in the gastrointestinal tract mostly occurs in the small bowel and liver. Hepatic deposition is not an uncommon consequence of amyloidosis, with one autopsy study identifying $70 \%$ of patients with primary amyloidosis having liver involvement. ${ }^{2}$ However clinical manifestations of hepatic amyloidosis are rare. A review of 98 patients with hepatic amyloidosis concluded that weight loss, hepatomegaly and elevated alkaline phosphatase levels should warrant consideration of primary amyloidosis. ${ }^{3}$ Hyperbilirubinaemia was a poor prognostic factor with a median survival of 1 month in patients with a level over $34 \mu \mathrm{mol} / \mathrm{L}$. If considered, systemic amyloidosis can be diagnosed

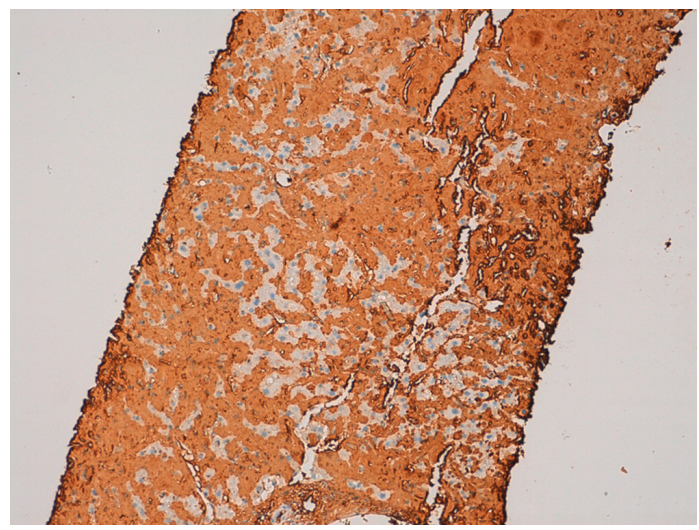

Figure 3 Hepatic amyloid deposition (lambda stain). 
through safer means such as subcutaneous fat or rectal biopsy, and liver biopsy is discouraged due to risk of bleeding.

The treatment for primary amyloidosis involves combination chemotherapy or autologous stem cell transplantation.

\section{Learning points}

In systemic amyloidosis, deposition of protein occurs in a variety of tissues, yet it is the degree of organ impairment inflicted by protein deposition that is clinically relevant. Clinical manifestations of hepatic amyloidosis are rare and it is type-dependent.

- Hyperbilirubinaemia is a poor prognostic factor in hepatic amyloidosis.

- Liver biopsy can lead to a definite diagnosis of hepatic amyloidosis. However, it is not a requirement and should be initially discouraged due to risk of bleeding, unless alternative diagnosis is considered. A rectal biopsy or subcutaneous fat biopsy carries a high yield in establishing a diagnosis and should be considered to remove the need for unnecessary organ biopsies.
Regression of the disease is slow and clinical improvement is often not apparent until 6-12 months after completion of chemotherapy. ${ }^{1}$ In view of progressive liver and renal involvement, aggressive treatment for this patient was deemed inappropriate due to a poor prognosis (estimated less than 6 weeks). He received best supportive care and died 3 months after admission.

Contributors MF and BD wrote the manuscript. VS has supplied the slides. SI has reviewed the manuscript and revised for content. All approved final version.

Competing interests None declared.

Patient consent Obtained.

Provenance and peer review Not commissioned; externally peer reviewed.

(C) BMJ Publishing Group Ltd (unless otherwise stated in the text of the article) 2018. All rights reserved. No commercial use is permitted unless otherwise expressly granted.

\section{REFERENCES}

1 National Amyloidosis Centre (UK). Amyloidosis Overview. London: University College London, 2017. (cited 6 Nov 2017).

2 Buck FS, Koss MN. Hepatic amyloidosis: morphologic differences between systemic AL and AA types. Hum Pathol 1991;22:904-7.

3 Park MA, Mueller PS, Kyle RA, et al. Primary (AL) hepatic amyloidosis: clinical features and natural history in 98 patients. Medicine 2003;82:291-8.

Copyright 2017 BMJ Publishing Group. All rights reserved. For permission to reuse any of this content visit http://group.bmj.com/group/rights-licensing/permissions.

BMJ Case Report Fellows may re-use this article for personal use and teaching without any further permission.

Become a Fellow of BMJ Case Reports today and you can:

- Submit as many cases as you like

- Enjoy fast sympathetic peer review and rapid publication of accepted articles

- Access all the published articles

Re-use any of the published material for personal use and teaching without further permission

For information on Institutional Fellowships contact consortiasales@bmjgroup.com

Visit casereports.bmj.com for more articles like this and to become a Fellow 